\title{
Effects Of Opioid Antagonists Naloxone and Naltrexone on Neuropeptide Y-induced Feeding and Brown Fat Thermogenesis in the Rat
} Neural Site of Action

\author{
Catherine M. Kotz, * Martha K. Grace," Jacquie Briggs; $\$$ Allen S. Levine, „\$\$ and Charles J. Billington \$\| \\ Departments of ${ }^{*}$ Food Science and Nutrition, ${ }^{\ddagger}$ Psychiatry, and ${ }^{\S}$ Medicine, University of Minnesota, Saint Paul, Minnesota 55108; and \\ "Veterans Affairs Medical Center, Minneapolis, Minnesota 55417
}

\begin{abstract}
Neuropeptide $Y$ administered intracerebroventricularly and into the paraventricular nucleus of the hypothalamus stimulates feeding and decreases brown adipose tissue thermogenesis. Although specific neuropeptide $Y$ antagonists are not yet available, previous studies had shown that the opioid antagonist naloxone blocked neuropeptide $Y$-induced feeding when both drugs were injected intracerebroventricularly. We wanted to find out if naloxone injected into specific brain sites would block neuropeptide $Y$ effects on feeding and brown fat thermogenesis. Rats were double injected in specific brain sites with neuropeptide $Y$ and either naloxone or naltrexone (a congener of naloxone). Food intake and brown fat measures were assessed. Naloxone or naltrexone in the paraventricular nucleus weakly decreased paraventricular nucleus neuropeptide $Y$-induced feeding and did not affect neuropeptide $Y$-induced reductions in brown fat activity. Peripheral naloxone blocked intracerebroventricular neuropeptide Y-induced feeding and brown fat alterations. Fourth ventricular naloxone decreased paraventricular nucleus neuropeptide $Y$-induced feeding, and naltrexone given into the nucleus of the solitary tract blocked paraventricular nucleus neuropeptide $Y$-induced alterations in feeding and brown fat. These data indicate that neuropeptide $Y$ in the paraventricular nucleus may act on feeding and brown fat thermogenesis through opioidergic pathways in the nucleus of the solitary tract. (J. Clin. Invest. 1995. 96:163-170.) Key words: neuropeptide • opioid • brain mapping • feeding behavior • energy metabolism

\section{Introduction}

Neuropeptide Y (NPY) ${ }^{1}$ was first characterized in 1982 by Tatemoto et al. (1) and is the most abundant peptide in the
\end{abstract}

Address correspondence to C. J. Billington, Veterans Affairs Medical Center, One Veterans Drive, Research Route 151, Minneapolis, MN 55417. Phone: 612-725-2000 ext. 4423; FAX: 612-725-2273; Internet: billi005@maroon.tc.umn.edu

Received for publication 27 April 1994 and accepted in revised form 22 March 1995.

1. Abbreviations used in this paper: 4thV, fourth cerebral ventricle; AP, area postrema; s.c., subcutaneous; BAT, brown adipose tissue; ICV, intracerebroventricular; NLX, naloxone; NPY, neuropeptide Y; NTS, nucleus of the solitary tract; NTX, naltrexone; PVN, paraventricular nucleus; SAL, saline; TBS, Tris-buffered saline; TTBS, Tris-buffered saline plus tween; UCP, uncoupling protein.

The Journal of Clinical Investigation, Inc.

Volume 96, July 1995, 163-170 brain (2). Centrally administered NPY is a powerful stimulus for feeding, whether in deprived or sated rats (3-5). The arcuate nucleus contains NPY producing cell bodies which project - to the paraventricular nucleus (PVN), and the PVN is densely populated with NPY nerve terminals (6). Deprivation results in increased NPY in the PVN (7) and NPY mRNA levels (8) in the arcuate nucleus. Recently, Kalra et al. have shown that release of NPY in the PVN rises before a meal and falls in response to that meal (9).

NPY also affects energy expenditure. PVN and intracerebroventricular (ICV) NPY injections increase lipoprotein lipase activity in white fat, thereby promoting energy storage, and concurrently decrease uncoupling protein (UCP) activity in brown fat, which may result in less energy wastage $(10,11)$. These metabolic effects of NPY are independent of the feeding status of ad-libitum fed NPY treated animals as the same results are found in pair-fed and food-deprived NPY-treated animals. NPY has also been shown to reduce sympathetic nervous system activity to brown fat (12). Thus it appears that NPY is involved in the regulation of feeding and energy expenditure, and the overall metabolic effect of NPY is energy storage. The mechanisms by which NPY exerts these effects on energy metabolism are not fully elucidated.

Opioids have been shown to be involved in the regulation of feeding. Naloxone, an opioid receptor antagonist, decreases food intake (13) and opioids increase food intake $(14,15)$. Naloxone given peripherally and intracerebroventricularly also reduces NPY-induced food intake $(4,16,17)$. The effect of naloxone on brown fat activity is unknown. Injection of $\beta$ endorphin has been reported to decrease sympathetic firing rate to BAT (18) which would presumably decrease brown fat activity. However, we found no effect of $\beta$-endorphin on brown fat UCP gene expression (unpublished observations). Although NPY is not an opioid and therefore would presumably not bind to or alter opioid receptors, it may affect opioidergic transmission in exerting its effects on feeding and brown fat.

Our purpose in these studies was to attempt separation of the metabolic effects of NPY administration into the PVN. The rationale was that although several energy metabolism effects are produced by NPY - increased food intake, decreased thermogenesis, and increased white fat storage - these effects can be presumed at some point in the efferent pathway to have separate neural substrates and therefore separate regulation and perhaps different associated neurotransmitters. Lacking a specific antagonist for NPY itself, and based on previous experience indicating that the unrelated opioid antagonist naloxone could block NPY actions, we proposed that opioid blockade might block one component of the NPY effect, such as feeding, and not another, such as brown fat thermogenesis. We have so far been unable to separate the feeding and metabolic effects of NPY by neuropharmacological manipulation. Our attempts 
to explore this hypothesis led to a different set of experiments in which we sought to locate the site at which opioid blockade also blocked PVN NPY effects. These data appear to establish a functional link between the PVN and the nucleus of the solitary tract in the brainstem.

\section{Methods}

\section{General experimental protocols}

Animals. Male Sprague-Dawley rats (Harlan, Madison, WI) weighing 231-436 grams were individually housed in conventional hanging cages with a $12 \mathrm{~h}$ light $/ 12 \mathrm{~h}$ dark photoperiod (lights on at 07.00 ) in a temperature controlled room $\left(21-22^{\circ} \mathrm{C}\right)$. Purina verified Lab Chow and water were allowed ad libitum, except where noted.

Surgery. Rats were anesthetized with Nembutal $(40 \mathrm{mg} / \mathrm{kg})$ and fitted with 23-gauge (PVN, fourth ventricle [4thV], and nucleus of the solitary tract [NTS] cannulations) or 20-gauge (ICV experiments) stainless steel guide cannulas (Plastics One, Austin, TX) placed into the PVN for experiments I, II, IV, and VI, ICV for experiment III, into the 4thV for experiment IV and into the nucleus of the solitary tract (NTS) for experiments V and VI. Stereotaxic coordinates were determined from the rat brain atlas by Paxinos and Watson (19) and were as follows: PVN cannulations: $0.5 \mathrm{~mm}$ lateral, $1.9 \mathrm{~mm}$ posterior to bregma, and $7.3 \mathrm{~mm}$ below the skull surface. ICV cannulations: 1.5 $\mathrm{mm}$ lateral, $1 \mathrm{~mm}$ posterior to bregma, and $3.5 \mathrm{~mm}$ below the skull surface. 4 thV cannulations: midline, $3 \mathrm{~mm}$ posterior to lambda, and 6.5 $\mathrm{mm}$ below the skull surface. NTS cannulations: $1.4 \mathrm{~mm}$ lateral, 3.3 $\mathrm{mm}$ posterior to lambda, and $7.2 \mathrm{~mm}$ below the skull surface. For all cannulations, the incisor bar was set at $3.3 \mathrm{~mm}$ below the ear bars. At least $7 \mathrm{~d}$ elapsed following surgery before experimental trials.

Injections. Peripheral injections were given in a $0.5 \mathrm{ml}$ volume. Ventricular injections were administered in a $5-\mu \mathrm{l}$ volume over $15 \mathrm{~s}$. Injections into the PVN and the NTS were given in a $1-\mu$ l volume over $30 \mathrm{~s}$. In experiment II, the first PVN injection was given in a $0.5-\mu \mathrm{l}$ volume over $15 \mathrm{~s}$ and the second PVN injection was given in a $1-\mu \mathrm{l}$ volume over $30 \mathrm{~s}$. In all experiments where double injections were given, there was at least a $30 \mathrm{~s}$ delay between injections.

Verification of cannula placement. After PVN, 4thV, and NTS experiments, brains were dissected out and stored in a $10 \%$ formaldehyde solution for later placement verification by histologic examination. For experiment III, correct placement was estimated prior to experimental testing by injecting $100 \mathrm{ng}$ angiotensin ICV and measuring water intake. Only those animals that drank greater than or equal to 5 grams of water within $30 \mathrm{~min}$ of angiotensin injection were used for experimental testing. After the experiment, ICV cannula placement was verified by injection of India ink followed by brain dissection to determine ventricular flow of the ink. Data from animals with incorrectly placed cannulas were discarded from the experiments

Drugs. Angiotensin was purchased from Sigma Chemical Co. (St. Louis, MO). Naloxone and naltrexone were purchased from RBI (Natick, MA). Porcine NPY was purchased from Peninsula Laboratories (Belmont, CA). All drugs were dissolved in $0.9 \%$ saline just before use

Food Intake Measurements. Food was allowed ad libitum until the start of each experimental trial. Just before injection, food was removed. Immediately after injection, pre-weighed pellets of chow were placed inside the rat cage. At selected time points, these pellets and collected spillage were weighed and subtracted from the initial weight to quantify the amount of food eaten.

UCP mRNA Determination. For experiments II, III, V, and VI, rats were killed by decapitation 1-2 $\mathrm{h}$ after the final set of injections and interscapular brown fat was dissected free from surrounding tissue. In experiments II, III, and V, the BAT pad was divided into two symmetrical pieces, one for UCP mRNA determination and one for UCP protein determination, and stored at $-70^{\circ} \mathrm{C}$. For the UCP mRNA determination, total RNA from brown fat was extracted by the rapid guanidine thiocyanate-phenol-chloroform method (20). Tissue was homogenized in a buffer containing $4 \mathrm{M}$ guanidine thiocyanate with added $\beta$-mercaptoethanol and water saturated molecular biology grade phenol. Sarcosyl, 2 $\mathrm{M}$ sodium acetate, and chloroform were then added. After centrifugation the aqueous phase was precipitated with isopropanol, resuspended in guanidine thiocyanate buffer and reprecipitated with isopropanol. The pellet was washed with $75 \%$ ethanol. The resulting RNA was stored in $100 \%$ ethanol at $-80^{\circ} \mathrm{C}$.

Aliquots of total RNA were dissolved in $7.4 \%$ formaldehyde: $6 \times$ SSC and denatured for $15 \mathrm{~min}$ at $65^{\circ} \mathrm{C} .1,2$, and $4 \mu \mathrm{g}$ of each sample was pipetted onto $6 \times$ SSC soaked nylon (Zetaprobe, Biorad Laboratories, Richmond, CA) using a slot blot apparatus. The RNA was fixed onto the nylon after air drying by UV cross-linking. Nylon filters were prewashed before use, and prehybridized overnight at $42^{\circ} \mathrm{C}$ in $50 \%$ formamide, $5 \times$ SSC, $10 \times$ Denhardt's solution, $0.2 \%$ SDS, and denatured salmon sperm DNA in $50 \mathrm{mM}$ Na phosphate, $\mathrm{pH}$ 6.5. Hybridization was at $42^{\circ} \mathrm{C}$ in $50 \%$ formamide, $5 \times$ SSC, $2 \times$ Denhardt's solution, $0.2 \%$ SDS, denatured salmon sperm DNA and yeast tRNA in $50 \mathrm{mM}$ Na phosphate, pH 6.5 with the addition of $10^{6} \mathrm{cpm} / \mathrm{ml}$ of [ $\left.{ }^{32} \mathrm{P}\right]-\mathrm{dCTP}$ UCP (UCP 365) labeled probe (generously supplied by Dr. Daniel Ricquier). After hybridization the filter was washed and exposed to x-ray film at $-80^{\circ} \mathrm{C}$. Quantification of autoradiograms was performed using 2-D densitometry.

UCP level determination. Frozen BAT was homogenized in $5 \mathrm{ml}$ buffer containing $250 \mathrm{mM}$ sucrose, $5 \mathrm{mM}$ TES, $2 \mathrm{mM}$ EDTA at a pH of 7.2. The mitochondria were washed by a differential centrifugation method (21) and washed with isolation buffer containing $1 \%$ bovine serum albumin. The BSA was removed with three successive washings of $250 \mathrm{mM}$ sucrose buffer at a pH of 7.2. After the final wash the mitochondrial pellets were resuspended in buffer to a concentration of $1.5 \mathrm{mg}$ protein $/ \mathrm{ml}$. Protein levels were determined by the Bradford method (22) with BSA as the standard. UCP levels were determined using a modified double antibody RIA method of Milner and Trayhurn (23). Samples were suspended in SDS Tris buffer and heated for $15 \mathrm{~min}$ at $55^{\circ} \mathrm{C}$ to solubilize the protein. Nitrocellulose filters were presoaked in Tris-buffered saline (TBS) and placed in a BioDot Microfiltration apparatus (BioRad Laboratories, Richmond, CA). Solubilized protein was then passively filtered for $30 \mathrm{~min}$, washed with TBS, and blocked with $1 \%$ BSA (RIA grade) in TBS by overnight passive filtration. The filter was rinsed with TBS $+0.05 \%$ Tween-20 (TTBS). Anti UCP serum in 1\% BSA TTBS was added and allowed to passively filter for $45 \mathrm{~min}$. The filter was then washed with TTBS. An ${ }^{125}$ I-labeled second antibody (Amersham IM 144) was added and allowed to passively filter for $\mathbf{4 5} \mathrm{min}$. Filters were washed with TTBS, and individual dots cut out of the filter and placed in a gamma counter to determine ${ }^{125} I$ levels for each sample. Sample levels were compared with standards which had been run on the same filter and used to generate a standard curve relating bound UCP to UCP levels. UCP antibody was generously supplied by Dr. Jean Himms-Hagen. UCP concentrations were corrected for the percent recovery of mitochondria. Mitochondrial recovery was determined by comparing the mitochondrial mass in known volumes of homogenate and final mitochondrial preparations as reflected by the activity of the mitochondrial marker enzyme, cytochrome c oxidase. Cytochrome c oxidase activity was assayed as previously described (24).

\section{Specific experimental protocols}

Experiment I: the effect of PVN and peripheral naloxone on PVN NPYinduced feeding. PVN cannulated rats received each of the following treatments with at least $5 \mathrm{~h}$ between each session: (a) PVN saline followed by PVN saline, (b) PVN saline followed by $1 \mu \mathrm{g}$ PVN NPY, (c) $50 \mu \mathrm{g}$ PVN naloxone followed by $1 \mu \mathrm{g}$ PVN NPY, (d) $100 \mu \mathrm{g}$ PVN naloxone followed by $1 \mu \mathrm{g}$ PVN NPY, and $(e) 5 \mathrm{mg} / \mathrm{kg}$ subcutaneous (s.c.) naloxone followed by $1 \mu \mathrm{g}$ PVN NPY. Food intake was measured at 1 and $2 \mathrm{~h}$ after injection.

Experiment II: the effect of PVN naltrexone on PVN NPY-induced feeding and brown fat activity. PVN cannulated rats were randomly assigned to four treatment groups: $(a)$ saline followed by saline, $(b)$ saline followed by $1 \mu \mathrm{g} \mathrm{NPY,} \mathrm{(c)} 50 \mu \mathrm{g}$ naltrexone followed by $1 \mu \mathrm{g}$ $\mathrm{NPY}$, or $(d) 50 \mu \mathrm{g}$ naltrexone followed by saline. Injections were given 
every $6 \mathrm{~h}$ for $24 \mathrm{~h}$. Food intake and brown fat UCP message and protein levels were measured.

Experiment III: the effect of peripheral naloxone on ICV NPYinduced feeding and brown fat activity. ICV cannulated rats were randomly assigned to three treatment groups: $(a)$ s.c. saline followed by ICV saline, (b) s.c. saline followed by $5 \mu \mathrm{g} \mathrm{ICV} \mathrm{NPY,} \mathrm{and} \mathrm{(c)} 5 \mathrm{mg} /$ $\mathrm{kg}$ s.c. naloxone followed by $5 \mu \mathrm{g}$ ICV NPY. The peripheral injections - were given every $2 \mathrm{~h}$ for $24 \mathrm{~h}$ and the ICV injections were given every $6 \mathrm{~h}$ for $24 \mathrm{~h}$. Food intake and brown fat UCP message and protein levels were measured.

Experiment IV: the effect of 4thV naloxone on PVN NPY-induced feeding. Rats fitted with two cannulas, one into the 4thV and one into the PVN were given four treatments: $(a) 4$ thV saline followed by PVN saline, (b) 4thV saline followed by $1 \mu \mathrm{g}$ PVN NPY, (c) $10 \mu \mathrm{g}$ 4thV naloxone followed by $1 \mu \mathrm{g}$ PVN NPY, and (d) $50 \mu \mathrm{g} 4$ thV naloxone followed by $1 \mu \mathrm{g}$ PVN NPY. Each rat received each treatment at least once with $\geq 1 \mathrm{~d}$ between treatments. Food intake was measured at 1 and $2 \mathrm{~h}$ after injection.

Experiment V: the effect of NTS naltrexone and NTS saline on food intake and brown fat activity. NTS cannulated rats were randomly assigned to 2 treatment groups and received either saline or $50 \mu \mathrm{g}$ naltrexone into the NTS every $6 \mathrm{~h}$ for $24 \mathrm{~h}$. Food intake and brown fat UCP message and protein levels were measured.

Experiment VI: the effect of NTS naltrexone on PVN NPY-induced feeding and brown fat activity. Rats were implanted with two cannulas: one into the PVN and one into the NTS, and were randomly assigned to three treatment groups. The treatments were as follows: $(a)$ NTS saline followed by PVN saline, $(b)$ NTS saline followed by $1 \mu \mathrm{g}$ PVN NPY, or (c) $50 \mu \mathrm{g}$ NTS naltrexone followed by $1 \mu \mathrm{g}$ PVN NPY. Injections were given every $6 \mathrm{~h}$ for $24 \mathrm{~h}$. Food intake and brown fat UCP message and protein levels were measured.

\section{Statistical design and analysis}

Experiments I and $I V$. In the analysis of these data, we first compared the saline group to the NPY group (no opioid antagonist) to evaluate whether NPY stimulated food intake. For all other comparisons, the no treatment (saline) group was eliminated from the analysis so that we could more accurately analyze the effect of opioid antagonist on NPYinduced feeding (only the NPY-treated and opioid antagonist plus NPYtreated animals were included). The data were analyzed by a randomized compact block ANOVA (block $=$ rat, compacted variable $=$ food intake) followed by Duncan's new multiple range post-hoc $t$ test to compare means. Data were also analyzed by ANOVA to determine whether there was an effect of day on food intake (dependent variable $=$ day, saline groups only). No effect of day on feeding response was found. Data are expressed as mean \pm SEM.

Experiments II, III, V, and VI. Data were analyzed by a two-factor ANOVA (naloxone or naltrexone $\times$ NPY) followed by multiple comparison contrasts to compare means. Data are expressed as mean \pm SEM.

\section{Results}

Experiment I. In this experiment, food intake was measured for two hours following NPY injection into the PVN along with: saline (5.9 \pm 0.6 grams); $50 \mu \mathrm{g}$ naloxone in the PVN $(4.8 \pm 0.8$ grams); $100 \mu \mathrm{g}$ naloxone in the PVN (3.6 \pm 0.2 grams); or 5 $\mathrm{mg} / \mathrm{kg}$ naloxone given subcutaneously $(1.5 \pm 0.4$ grams $)$. The control group was saline only in the PVN $(1.1 \pm 0.2$ grams $)$. An ANOVA including the PVN NPY alone, $50 \mu \mathrm{g}$ PVN naloxone + PVN NPY, and $100 \mu \mathrm{g}$ PVN naloxone + PVN NPY treated groups showed a significant main effect of PVN naloxone on PVN NPY-induced feeding $(\mathrm{F}=3.702, P<0.05$, ). Naloxone significantly reduced PVN NPY-induced food intake $(0-2 \mathrm{~h})$ when $100 \mu \mathrm{g}$ were injected PVN and $5 \mathrm{mg} / \mathrm{kg}$ were injected subcutaneously $(P<0.01)$. The peripheral naloxone was clearly more potent at suppressing NPY induced feeding than either dose of PVN naloxone.

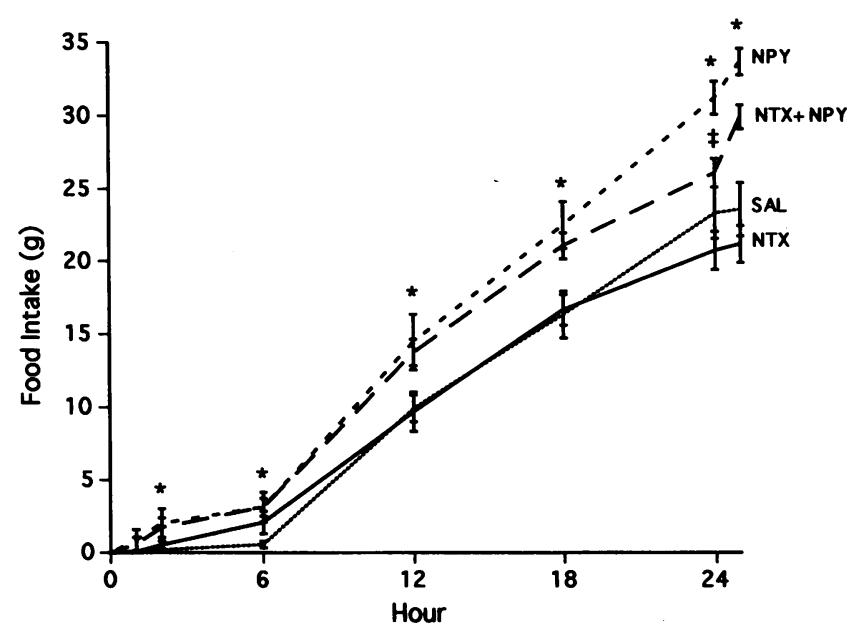

Figure 1. The effect of PVN naltrexone ( $50 \mu \mathrm{g}$ every $6 \mathrm{~h}$ for $24 \mathrm{~h}$ ) on PVN NPY ( $1 \mu \mathrm{g}$ every $6 \mathrm{~h}$ for $24 \mathrm{~h})$ induced feeding (Experiment II). Values represent grams of chow and are expressed as mean \pm SEM. ${ }^{*} P$ $<0.01$ compared with SAL and NTX groups. ${ }^{\ddagger} P<0.05$ compared with NPY group. $n=6-8$ rats per group.

Experiment II. In this experiment, rats were coinjected with $\mathrm{NPY} \pm$ naltrexone into the PVN every $6 \mathrm{~h}$ for $24 \mathrm{~h}$. Naltrexone, a congener of naloxone, significantly decreases NPY-induced feeding for $6 \mathrm{~h}$ after ICV injection of naltrexone and NPY (0-6 $\mathrm{h}$ food intake: sal + NPY treated rats: $8.3 \pm 0.9$ grams; naltrexone + NPY treated rats: $4.4 \pm 0.8$ grams; $P=0.0006$ ). PVN NPY significantly increased feeding at $2 \mathrm{~h}$ and all subsequent cumulative feeding intervals $(P<0.05$, Fig. 1). PVN naltrexone did not significantly reduce PVN NPY-induced food intake $(P>0.05$, Fig. 1). There was no significant difference in total food intake in the NPY-treated and NPY + NTX treated animals at study's end. PVN NPY significantly increased brown fat pad weight $(P<0.05)$ and PVN naltrexone did not block this increase. UCP mRNA and UCP protein levels were significantly decreased $(P<0.01)$ in the NPY treated group and PVN naltrexone did not block this decrease (Fig. 2). Thus, PVN naltrexone weakly blocked PVN NPY-induced feeding and did not alter NPY's effect on brown fat.

Experiment III. In this experiment, rats were injected with ICV NPY every $6 \mathrm{~h}$ and naloxone peripherally (subcutaneous, s.c.) every $2 \mathrm{~h}$. Peripheral naloxone significantly decreased ICV NPY-induced food intake (ANOVA F $=7.443, P=.0044$, Table I). In addition, peripheral naloxone significantly blocked ICV NPY-induced increase in brown fat pad weight and ICV NPY suppression of UCP gene expression $(P<.05$, Table I). UCP protein levels were significantly decreased by ICV NPY $(P<.05$, Table I $)$, and UCP levels of naloxone + NPY treated animals were not significantly different from controls, consistent with naloxone blockade of NPY.

Experiment IV. In this experiment, rats were given an injection of naloxone (10 or $50 \mu \mathrm{g})$ into the fourth ventricle just before injection of $1 \mu \mathrm{g}$ NPY into the PVN. As shown in Fig. $3,50 \mu \mathrm{g}$ of 4 thV naloxone significantly decreased PVN NPYinduced feeding $(P<0.05)$ at 1 and $2 \mathrm{~h}$ after injection.

Experiment $V$. In this experiment, animals were injected with saline or naltrexone into the NTS every $6 \mathrm{~h}$ for $24 \mathrm{~h}$. As shown in Table II, there was no significant difference in food intake between naltrexone- and saline-treated animals. In addi- 


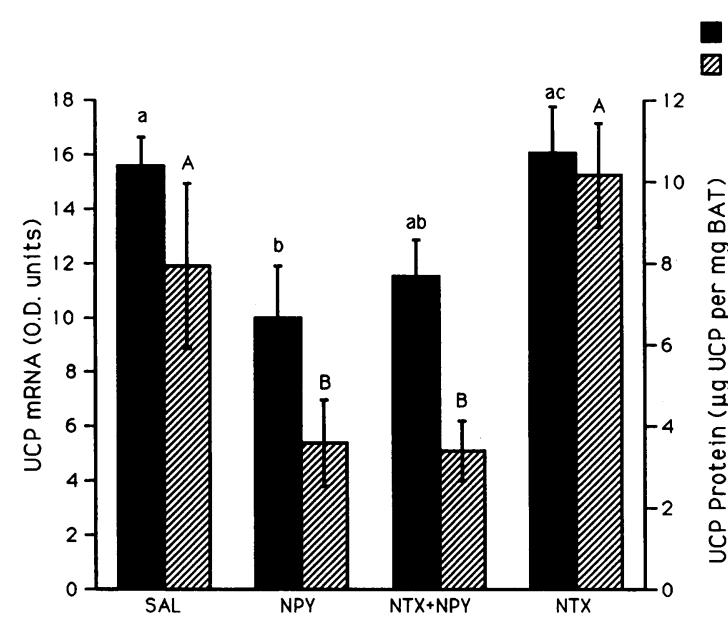

Figure 2. The effect of PVN naltrexone ( $50 \mu \mathrm{g}$ every $6 \mathrm{~h}$ for $24 \mathrm{~h}$ ) on PVN NPY ( $1 \mu \mathrm{g}$ every $6 \mathrm{~h}$ for $24 \mathrm{~h})$ induced decrease in UCP mRNA and UCP protein levels (Experiment II). UCP mRNA are represented as O.D. units (arbitrary units) and are means \pm SEM. UCP proteins represent $\mu \mathrm{g}$ per mg brown fat (values are corrected for percent mitochondria recovery).and are means \pm SEM. Bars not sharing common superscripts (within uppercase or lowercase versions) indicate that the representative values are significantly different, $P<0.05 . n=6-8$ rats per group.

tion, there were no significant differences in brown fat pad weight, brown fat UCP mRNA levels or UCP protein levels between saline and naltrexone treated animals (Table II).

Experiment VI. In this experiment, rats were injected with naltrexone into the NTS and with NPY into the PVN every 6 $\mathrm{h}$ for $24 \mathrm{~h}$. As shown in Fig. 4, the food intake of the naltrexone+NPY-treated animals was significantly lower $(P$ $<0.05$ ) than that of the NPY treated animals and was not significantly different from the controls. In addition, naltrexone in the NTS blocked PVN NPY-induced alterations in brown fat. The BAT pad weights of the saline and naltrexone + NPY treated animals were similar and lower than that of the NPY

Table I. The Effect of Peripheral Naloxone on ICV NPY-induced Changes in Food Intake, BAT Weight, UCP mRNA and Protein Levels (Experiment III)

\begin{tabular}{|c|c|c|c|c|c|}
\hline \multicolumn{2}{|c|}{$\begin{array}{l}\text { Injection site } \\
\text { and treatment }\end{array}$} & \multirow[b]{2}{*}{25 h F.I. } & \multicolumn{3}{|c|}{ Brown adipose tissue measures } \\
\hline s.c. & ICV & & BAT weight & UCP mRNA & UCP Protein \\
\hline & & $g$ & $m g / \log B W W$ & O.D. units & $\mu g$ UCP/mg PRO \\
\hline Saline & Saline & $20 \pm 2 *$ & $77 \pm 5^{*}$ & $36 \pm 2 *$ & $149 \pm 10 *$ \\
\hline Saline & NPY & $28 \pm 2^{\ddagger}$ & $109 \pm 12^{\ddagger}$ & $30 \pm 2^{\ddagger}$ & $103 \pm 15^{\ddagger 8}$ \\
\hline NLX & NPY & $16 \pm 2 *$ & $72 \pm 6^{*}$ & $37 \pm 2 *$ & $131 \pm 11^{* 8}$ \\
\hline
\end{tabular}

The dose of naloxone was $5 \mathrm{mg} / \mathrm{kg}$ (every $2 \mathrm{~h}$ for $24 \mathrm{~h}$ ) and the dose of NPY was $5 \mu \mathrm{g}$ (every $6 \mathrm{~h}$ for $24 \mathrm{~h}$ ). F.I., food intake. BAT weight is expressed as mg BAT per 100 gram body weight. O.D. units are arbitrary units. UCP levels are expressed as $\mu \mathrm{g}$ UCP per mg mitochondrial protein and are not corrected for percent mitochondrial recovery (data not available). Values represent mean \pm SEM, and values within columns that do not share common superscripts are significantly different, $P<0.05 . n=8$ rats per group.

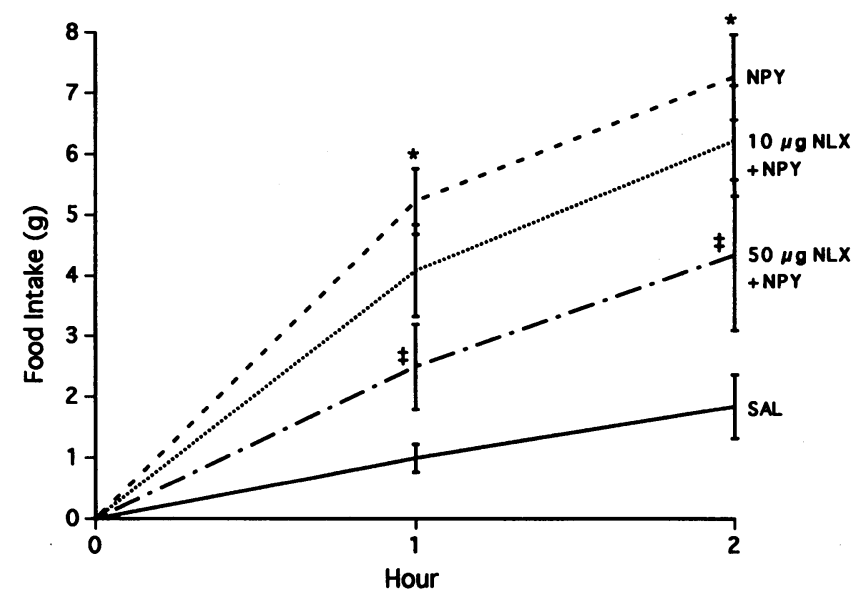

Figure 3. The effect of 4 thV naloxone ( 10 and $50 \mu \mathrm{g}$ ) on PVN NPY $(1 \mu \mathrm{g})$-induced feeding (Experiment IV). Values represent grams of chow and are expressed as mean \pm SEM. $* P<0.01$ compared with SAL group. ${ }^{\ddagger} P<0.01$ compared with NPY group. $n=9$ rats per group.

treated animals, although these differences were not statistically significant. The UCP message levels were significantly higher $(P<0.05$, Fig. 5) in the saline and naltrexone + NPY treated animals than in the NPY treated animals.

\section{Discussion}

The neural pathway by which NPY induces feeding is not known. NPY affects energy balance (25) and decreases brown adipose tissue thermogenesis (11) by decreasing sympathetic nervous system activity to brown fat (12). The purpose of the present experiments was to examine the neural pathway by which NPY affects energy balance. Our first experiment was based on previous observations indicating that naloxone (2.3$50 \mu \mathrm{g}$ ) in the PVN decreases deprivation-induced food intake $(26,27)$. Further, naloxone administered ICV was reported to block NPY-induced feeding at doses of 10 (16) and $25 \mu \mathrm{g}$ (17). PVN naloxone administration effects on PVN NPY-induced feeding had not been previously tested. We thought PVN naloxone would block PVN NPY-induced feeding and hypothesized that naloxone may also reverse NPY's effects on brown fat,

Table II. The Effect of NTS Naltrexone on Food Intake, BAT Weight, UCP mRNA, and Protein Levels (Experiment V)

\begin{tabular}{|c|c|c|c|c|}
\hline \multirow{2}{*}{$\begin{array}{c}\begin{array}{c}\text { Injection site } \\
\text { and treatment }\end{array} \\
\text { NTS }\end{array}$} & \multirow[b]{2}{*}{25 h F.I. } & \multicolumn{3}{|c|}{$\begin{array}{l}\text { Brown adipose tissue } \\
\text { measures }\end{array}$} \\
\hline & & BAT weight & UCP mRNA & UCP protein \\
\hline & $g$ & $m g / 100 g B W$ & O.D. units & $\mu g U C P / m g B A T$ \\
\hline Saline & $14 \pm 2$ & $95 \pm 6$ & $8 \pm 2$ & $15.0 \pm 3.3$ \\
\hline NTX & $11 \pm 2$ & $98 \pm 5$ & $11 \pm 2$ & $12.4 \pm 2.5$ \\
\hline
\end{tabular}

The dose of naltrexone was $50 \mu \mathrm{g}$ (every $6 \mathrm{~h}$ for $24 \mathrm{~h}$ ). F.I., food intake. BAT weight is expressed as mg BAT per 100 gram body weight. O.D. units are arbitrary units. UCP protein levels are expressed as $\mu$ g UCP per mg brown fat and are corrected for percent mitochondrial recovery. Values represent mean \pm SEM. $n=5-6$ rats per group. 


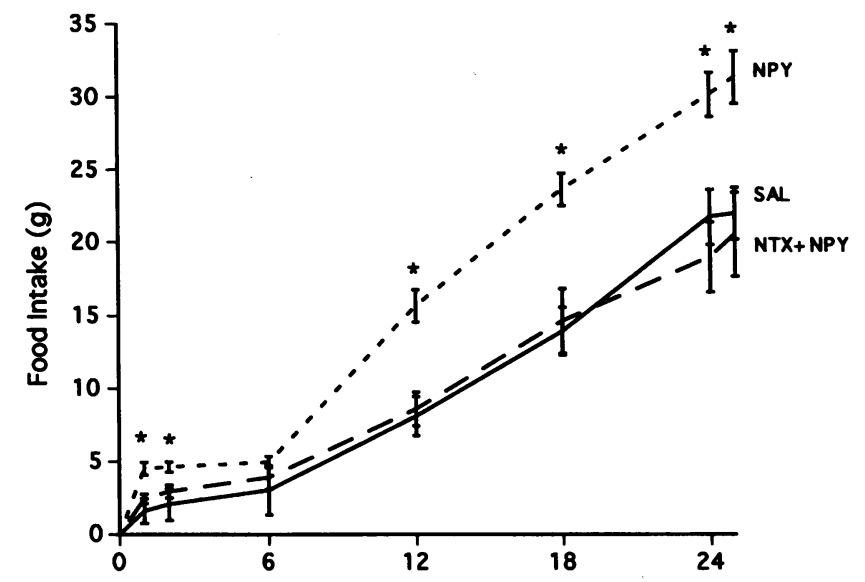

Figure 4. The effect of NTS naltrexone ( $50 \mu \mathrm{g}$ every $6 \mathrm{~h}$ for $24 \mathrm{~h})$ on PVN NPY ( $1 \mu \mathrm{g}$ every $6 \mathrm{~h}$ for $24 \mathrm{~h}$ ) induced food intake (Experiment VI). Values represent grams of chow and are expressed as mean \pm SEM. $* P<0.05$ compared with SAL and NTX + NPY groups. $n=6-7$ rats per group.

namely an increase in BAT weight and a decrease in UCP gene expression and UCP level.

However, in experiments I and II, naloxone or naltrexone given into the PVN had a relatively weak effect on PVN NPYinduced feeding and no effect on brown fat (Figs. 1 and 2), indicating that the PVN is not the site at which naloxone or naltrexone antagonize NPY effects. We have not ruled out an effect of high dose PVN naltrexone on PVN NPY-induced changes in brown fat activity, but it is clear that any such effects will be at doses higher than seen with ICV naloxone blockade of ICV NPY feeding effects $(4,16,17)$. These data suggest that the PVN is relatively insensitive to naloxone and naltrexone blockade with respect to PVN NPY-induced feeding and BAT effects. It is unlikely that antagonism of opioid receptors at NPY's site of action (PVN) importantly affects PVN NPY effects on feeding or brown fat.

In experiment I, peripheral naloxone was more effective at blocking PVN NPY-induced feeding than the highest dose of naloxone given into the PVN. In experiment III, peripheral naloxone clearly blocked ICV NPY-induced feeding and changes in brown fat (Table I). Thus naloxone more potently blocked PVN NPY effects when given peripherally than when given into the PVN. This suggests that naloxone acts either at some other brain site (as naloxone is able to cross the blood brain barrier) or that naloxone acts in the periphery to block NPY's effects. Based on evidence indicating a central (vs. peripheral) role for opioids in feeding $(14,28)$, we hypothesized that naloxone acts at a central site (other than the PVN) to block NPY's effects.

Several studies indicate that the hindbrain is involved in feeding (29) which led us to test whether naloxone administered into the fourth ventricle would antagonize PVN NPY-induced feeding. As shown in Fig. 3, $50 \mu \mathrm{g}$ naloxone in the fourth ventricle blocked the feeding effect of NPY in the PVN in the first hour after administration. Based on this indication that the hindbrain may be involved in NPY-induction of feeding, we next chose to examine the nucleus of the solitary tract, a hindbrain structure. The nucleus of the solitary tract receives descending PVN neural projections that are involved in feeding $(30,31)$, and the NTS contains relatively high concentrations

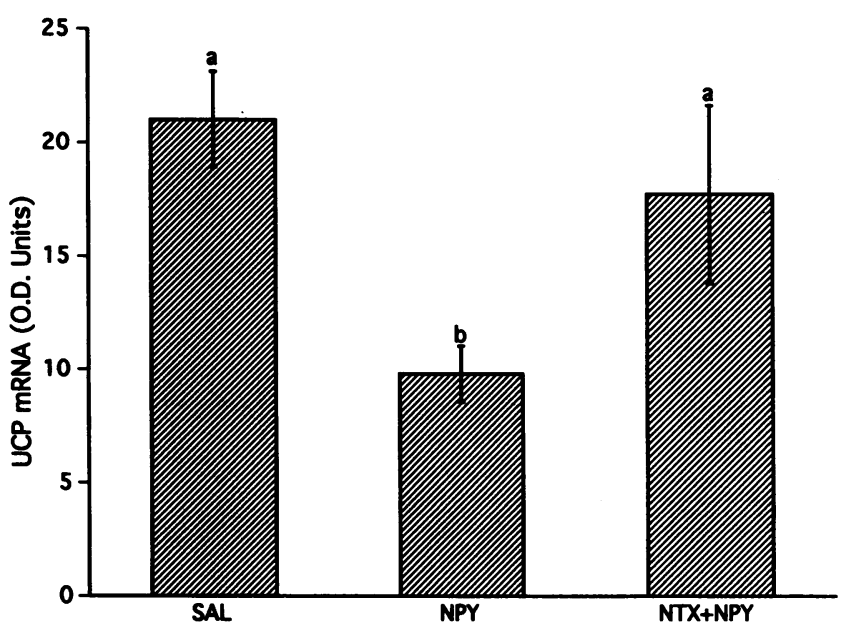

Figure 5. The effect of NTS naltrexone ( $50 \mu \mathrm{g}$ every $6 \mathrm{~h}$ for $24 \mathrm{~h}$ ) on PVN NPY ( $1 \mu \mathrm{g}$ every $6 \mathrm{~h}$ for $24 \mathrm{~h})$ induced changes in UCP mRNA levels (Experiment VI). Values represent UCP mRNA O.D. units (arbitrary units) and are expressed as mean \pm SEM. Bars not sharing common superscripts indicate that the representative values are significantly different, $P<0.05$. $n=6-7$ rats per group.

of mu and kappa opioid receptors (32). Naltrexone alone in the nucleus of the solitary tract did not impact feeding or brown fat activity (Table II). However, administration of naltrexone into the NTS resulted in complete blockade of PVN NPYinduced increases in feeding (Fig. 4), and blocked NPY-induced reduction in brown fat activity as measured by UCP message levels (Fig. 5).

We also attempted to separate the feeding and metabolic effects of NPY. However, in all experiments we found the feeding and metabolic effects to be inversely related. This fits with the hypothesis of Bray and colleagues that there is a reciprocal interaction between food intake and the sympathetic nervous system (SNS) that has been observed for several peptides (33). In this hypothesis, feeding results in increased SNS activity which then provides a feedback signal to the brain to cause cessation of feeding. This hypothesis is consistent with the present data because food was allowed ad-libitum in all experiments. However, in previous studies in our laboratory, we have found that the effect of NPY on brown adipose tissue thermogenesis is independent of food intake as the same results are found in food deprived and pair-fed NPY treated rats $(10,11)$. Thus the increased feeding observed after NPY, although inversely related to the effect observed in the BAT (decreased BAT activity), must not be responsible for the effect observed in the BAT, indicating the existence of separate neural pathways for NPY effects on feeding and thermogenesis.

The results of the present experiments suggest that NPY may exert its effects on feeding and brown fat through opioidergic pathways in the NTS. One hypothesis for the mechanism by which this may occur is depicted in Fig. 6. In this hypothesis, NPY in the PVN may interact with NPY receptors on opioidsynthesizing cell bodies in the PVN, resulting in increased opioid synthesis in the PVN. Mature opioid peptide would be released from the nerve ending in the NTS where it binds to NTS opioid receptors to elicit feeding and to decrease BAT thermogenesis. NPYergic and opioidergic synaptic contacts have been reported in the basal medial hypothalamus $(34,35)$, 


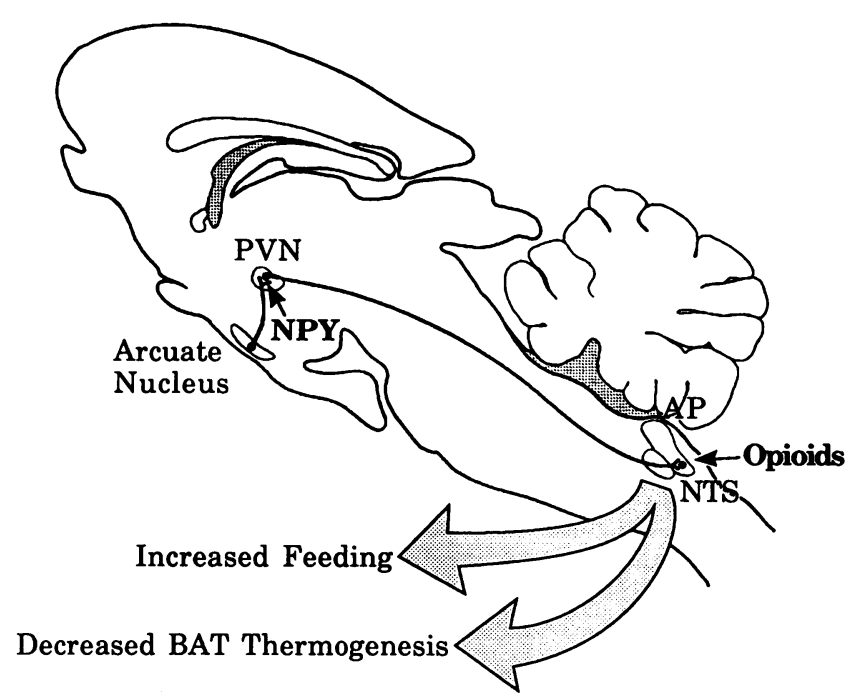

Figure 6. Hypothesized PVN-NPY-NTS-opioid pathway that stimulates feeding and decreases brown adipose tissue thermogenesis. $P V N$, paraventricular nucleus; $N P Y$, neuropeptide Y; $N T S$, nucleus of the solitary tract; $A P$, area postrema; $B A T$, brown adipose tissue.

which may parallel the possible NPY-opioid connections in the PVN. Although opioid agonists in the NTS have not been tested for effects on feeding, there is a large amount of data to show that lesions of the area postrema (AP) with surrounding NTS results in alterations in food intake $(29,36,37)$. The AP lies adjacent to the caudal NTS and the two structures innervate each other $(38,39)$. AP lesions result in increased consumption of palatable foods (40) and decreased glucoprivic feeding (41). These lesions usually include the adjacent NTS and are often referred to as AP/NTS lesions. These data lend support to the idea that the NTS is involved in a feeding regulatory pathway.

There is increasing evidence of a central NPY-opioid connection in relation to feeding. Central administration of opioids increases feeding (14), although the effect is not as strong as central NPY-induction of feeding. Naloxone and naltrexone decrease NPY-induced feeding (4). ICV pre-treatment with either norBNI (kappa opioid receptor antagonist) or $\beta$-FNA (mu opioid receptor antagonist) significantly decreased NPY induced feeding, whereas NTI (delta opioid receptor antagonist) had no effect, suggesting that the mu and kappa opioid receptors may be involved in NPY's feeding effects (42). Lambert et al have also recently reported that antisense oligonucleotide to endogenous dynorphin decreases NPY-induced feeding (43, 44 ), indicating involvement of the kappa opioid receptor in NPY induced feeding.

In our hypothesis, PVN NPY may result in opioid release in the NTS. If this pathway is involved in food intake regulation, one might expect that opioid release may provide a negative feedback signal to NPYergic activity, and that blockade of opioid receptors may prevent this feedback signal. This idea is supported by studies which indicate NPY-opioid connections in other systems. For instance, stimulation of opioid receptors by chronic morphine administration resulted in decreased hypothalamic and striatal NPY levels but not NPY in the hippocampus or cortex (45). Conversely, blockade of opioid receptors by intraatrial naloxone infusions resulted in increased hypothalamic NPY protein levels in $\beta$-estradiol-primed ovariectomized rats and in vitro release of NPY from the mediobasal hypothalamus was dose-dependently increased with naloxone (46). Increases in plasma NPY by naloxone administration has also been reported (47).

In our interpretation of the present data, we hypothesize that the opioid receptors in the NTS are involved in an NPY efferent pathway affecting energy balance. It is also possible that the NTS is part of an afferent pathway that modulates hypothalamic NPY activity. The NTS has afferent projections to the hypothalamus and relays information from the periphery to the brain (48). Thus there is the potential that feeding-related signals originating in the NTS may affect endogenous hypothalamic neuropeptide $Y$ synthesis and release mechanisms, and blockade of NTS opioid receptors could impact these signals. However, we found no effect of NTS naltrexone on normal feeding or brown fat activity (Table II). In the present studies we did not test this hypothesis of afferent modulation of NPY, but rather, we looked at blockade and non-blockade of the effects of exogenous NPY administered into the hypothalamic PVN.

Although the present studies implicate the NTS in NPY's effects on feeding and brown fat, other neural sites may be involved. For instance, the AP, which lies in close proximity to the NTS, receives second order neural projections from, and innervates, the NTS (29). Also, substances injected into the NTS may diffuse into the AP (29). Thus, the AP cannot be ruled out as a potential site involved in PVN NPY effects on energy balance. Several parabrachial subnuclei receive secondorder afferent projections from the NTS and the parabrachial nucleus also has efferent projections to the NTS (48). The parabrachial nucleus has reciprocal neural connections with the AP and the PVN (48), and has been reported to be involved in feeding $(49,50)$ and thus could also have a potential role in NPY's effects.

NPY may be involved in the etiology of obesity, a risk factor for several diseases. Brain NPYergic activity is increased in animal models of obesity (51), indicating a potential role for NPY in animal obesity. Whether NPY is involved in human obesity is speculative, but the effects of NPY - increased energy intake and decreased energy expenditure-parallel the predictors of human obesity. For instance, Pima Indians, an obesity prone population, have increased energy intake and it has recently been demonstrated by the doubly labeled water method that this group also have decreased energy expenditure (52). The present data may help to broaden the knowledge base of NPY neural pathways in relation to energy balance, a preliminary step for the development of anti-obesity drugs.

In summary, the injection of PVN NPY may exert its effects on feeding and brown fat via opioid receptors in the NTS. This was demonstrated in the present experiments by the observation that NTS naltrexone blocked PVN NPY-induced feeding and inhibition of brown fat activity whereas PVN naltrexone had a weak effect on PVN NPY-induced feeding and no effect on PVN NPY reduction of brown fat activity. We did not demonstrate separate pathways for the feeding and metabolic effects of NPY, as blockade (or non-blockade) of NPY's feeding effect was accompanied by blockade (or non-blockade) of NPY's effect on brown fat activity (Table III). Further investigation into PVN NPY neurotransmission is needed to determine whether other neural sites are involved, where the transmission of the NPY energy metabolism signal goes after the NTS, and whether the PVN NPY feeding stimulatory pathway and PVN 
Table III. Summary of the Effects of Naloxone and Naltrexone on NPY-induced Feeding and Brown Fat Measures

\begin{tabular}{lccccc}
\hline \multicolumn{2}{c}{ Treatment and injection site } & & \multicolumn{2}{c}{ Parameter } \\
\cline { 1 - 3 } NLX or NTX & NPY & & Experiment No. & Food Intake & BAT Measures \\
\hline PVN (NLX) & PVN & I & $(-)^{*}$ & N.M. $^{\dagger}$ \\
s.c. (NLX) & PVN & I & $(+)$ & N.M. \\
PVN (NTX) & PVN & II & $(-)$ & $(-)$ \\
s.c. (NLX) & ICV & III & $(+)$ & $(+)$ \\
4thV (NLX) & PVN & IV & $(+)$ & N.M. \\
NTS (NTX) & N.A. & V & $(-)$ & $(-)$ \\
NTS (NTX) & PVN & VI & $(+)$ & $(+)$ \\
\hline
\end{tabular}

* $(-)$ indicates that NPY-induced measured parameter was not blocked, and $(+)$ indicates that NPY-induced measured parameter was blocked by opioid antagonist treatment. ${ }^{\dagger}$ N.M. indicates that parameter was not measured. ${ }^{8}$ N.A., not applicable because NPY was not injected in this study and thus measured parameters were not "NPY-induced."

NPY brown fat inhibitory pathway diverge further along NPY's efferent pathway.

\section{Acknowledgments}

This work was supported by the Department of Veterans Affairs, the National Institutes of Health DK-42698 and the National Institute of Drug Abuse DA-03999.

\section{References}

1. Tatemoto, K., M. Carlquist, and V. Mutt. 1982. Neuropeptide Y-a novel brain peptide with structural similarities to peptide $Y Y$ and pancreatic polypeptide. Nature (Lond.). 296:659-660.

2. Allen, Y. S., T. E. Adrian, J. M. Allen, K. Tatemoto, T. J. Crow, S. R. Bloom, and J. M. Polak. 1983. Neuropeptide Y distribution in the rat brain. Science (Wash. DC). 221(4613):877-879.

3. Clark, J. T., P. S. Kalra, W. R. Crowley, and S. P. Kalra. 1984. Neuropeptide $\mathrm{Y}$ and human pancreatic polypeptide stimulate feeding behavior in rats. Endocrinology. 115(1):427-429.

4. Levine, A. S., and J. E. Morley. 1984. Neuropeptide Y: a potent inducer of consummatory behavior in rats. Peptides. 5(6):1025-1029.

5. Stanley, B. G., and S. F. Leibowitz. 1984. Neuropeptide Y: stimulation of feeding and drinking by injection into the paraventricular nucleus. Life Sci. 35(26):2635-2642.

6. Bai, F. L., M. Yamano, Y. Shiotani, P. C. Emson, A. D. Smith, J. F. Powell, and M. Tohyama. 1985. An arcuato-paraventricular and -dorsomedial hypothalamic neuropeptide Y-containing system that lacks noradrenaline in the rat. Brain Res. 331:172-175.

7. Beck, B., M. Jhanwar-Uniyal, A. Burlet, M. Chapleur-Chateau, S. F. Leibowitz, and C. Burlet. 1990. Rapid and localized alterations of neuropeptide Y in discrete hypothalamic nuclei with feeding status. Brain Res. 528(2):245-249.

8. Chua, S. C., R. L. Leibel, and J. Hirsch. 1991. Food deprivation and age modulate neuropeptide gene expression in murine hypothalamus and adrenal gland. Mol. Brain Res. 9:95-101.

9. Kalra, S. P., M. G. Dube, A. Sahu, C. P. Phelps, and P. S. Kalra. 1991. Neuropeptide $\mathrm{Y}$ secretion increases in the paraventricular nucleus in association with increased appetite for food. Proc. Natl. Acad. Sci. USA. 88:10931-10935.

10. Billington, C. J., J. E. Briggs, M. Grace, and A. S. Levine. 1991. Effects of intra-cerebroventricular injection of neuropeptide $\mathrm{Y}$ on energy metabolism. Am. J. Physiol. 260(2 Pt 2):R321-327.

11. Billington, C. J., J. E. Briggs, S. Harker, M. Grace, and A. S. Levine. 1994. Neuropeptide $Y$ in hypothalamic paraventricular nucleus: a center coordinating energy metabolism. Am. J. Physiol. 266(R1765-R1770).

12. Egawa, M., H. Yoshimatsu, and G. A. Bray. 1991. Neuropeptide Y suppresses sympathetic activity to interscapular brown adipose tissue in rats. Am. J. Physiol. 260(2 Pt 2):R328-334.

13. Holtzman, S. G. 1979. Suppression of appetitive behavior in the rat by naloxone: lack of effect of prior morphine dependence. Life Sci. 24(3):219-226.

14. Levine, A. S., J. E. Morley, B. A. Gosnell, C. J. Billington, and T. J.
Bartness. 1985. Opioids and consummatory behavior. Brain Res. Bull. 14(6):663-672.

15. Morley, J. E. 1987. Neuropeptide regulation of appetite and weight gain. Endocrinol. Rev. 8:256-287.

16. Levine, A. S., M. Grace, and C. J. Billington. 1990. The effect of centrally administered naloxone on deprivation and drug-induced feeding. Pharmacol. Biochem. Behav. 36(2):409-412.

17. Schick, R. R., V. Schusdziarra, C. Nussbaumer, and M. Classen. 1991. Neuropeptide $\mathrm{Y}$ and food intake in fasted rats: effect of naloxone and site of action. Brain Res. 552(2):232-239.

18. Egawa, M., H. Yoshimatsu, and G. A. Bray. 1993. Effect of beta-endorphin on sympathetic nerve activity to interscapular brown adipose tissue. Am. J. Physiol. 264( 1 Pt 2):R109-115.

19. Paxinos, G., and C. Watson. 1990. The Rat Brain in Stereotaxic Coordinates. Academic Press, San Diego.

20. Chomczynski, P., and N. Sacchi. 1987. Single-step method of RNA isolation by acid guanidinium thiocyanate-phenol-chloroform extraction. Anal. Biochem. 162:156-159.

21. Cannon, B., and O. Lindberg. 1979. Mitochondria from brown adipose tissue: isolation and properties. Methods Enzymol. 55:65-78.

22. Bradford, M. M. 1976. A rapid and sensitive method for the quantitation of microgram quantities of protein utilizing the principle of protein-dye binding. Anal. Biochem. 72:248-254.

23. Milner, R. E., and P. Trayhurn. 1990. Rapid quantitation of uncoupling protein in brown adipose tissue mitochondria by a dot immunobinding ("dot blot") procedure: application to the measurement of uncoupling protein in Richardson's ground squirrel, rats, and mice. Biochem. Cell Biol. 68:973-979.

24. Billington, C. J., T. J. Bartness, J. Briggs, A. S. Levine, and J. E. Morley. 1987. Glucagon stimulation of brown adipose tissue growth and thermogenesis. Am. J. Physiol. 252:R160-R165.

25. Menendez, J., I. McGregor, P. Healey, D. Atrens, and S. Leibowitz. 1990. Metabolic effects of neuropeptide $\mathrm{Y}$ injections into the paraventricular nucleus of the hypothalamus. Brain Res. 516:8-14.

26. Woods, J. S., and S. F. Leibowitz. 1985. Hypothalamic sites sensitive to morphine and naloxone: effects on feeding behavior. Pharmacol. Biochem. Behav. $23(3): 431-438$.

27. Gosnell, B. A., J. E. Morley, and A. S. Levine. 1986. Opioid-induced feeding: localization of sensitive brain sites. Brain Res. 369:177-184.

28. Morley, J. E., A. S. Levine, B. A. Gosnell, J. E. Mitchell, D. D. Krahn, and S. E. Nizielski. 1985. Peptides and feeding. Peptides. 2:181-192.

29. Ritter, R. C., S. Ritter, and C. D. Barnes. 1986. Research Topics in Physiology; Feeding Behavior; Neural and Humoral Controls. Academic Press, London. $357 \mathrm{pp}$.

30. Weiss, G. F., and S. F. Leibowitz. 1985. Efferent projections from the paraventricular nucleus mediating alpha 2-noradrenergic feeding. Brain Res. $347(2): 225-238$

31. Kirchgessner, A. L., and A. Sclafani. 1988. PVN-hindbrain pathway involved in the hypothalamic hyperphagia-obesity syndrome. Physiol. Behav. 42(6):517-528.

32. Mansour, A., M. E. Khachaturian, H. Lewis, H. Akil, and S. J. Watson. 1985. Anatomy of CNS opioid receptors. Trends Neurosci. 11:308-314.

33. Bray, G. A. 1993. The nutrient balance hypothesis: peptides, sympathetic activity, and food intake. Ann. NY Acad. Sci. 676:223-241.

34. Horvath, T. L., F. Naftolin, S. P. Kalra, and C. Leranth. 1992. Neuropeptide-Y innervation of $\beta$-endorphin-containing cells in the rat mediobasal hypothalamus. Endocrinology. 131(5):2461-2467.

35. Csiffary, A., T. J. Gorcs, and M. Palkovits. 1990. Neuropeptide Y innervation of ACTH-immunoreactive neurons in the arcuate nucleus of rats: a correlated light and electron microscope double immunolabelling study. Brain Res. 506:215222.

36. Ritter, R. C., and G. L. Edwards. 1984. Area postrema lesions cause overconsumption of palatable foods but not calories. Physiol. Behav. 32(6):923927.

37. Ritter, S., and S. L. Stone. 1987. Area postrema lesions block feeding induced by systemic injections of monosodium glutamate. Physiol. Behav. 41( 1$): 21-4$.

38. van der Kooy, D., and L. Y. Koda. 1983. Organization of the projections of a circumventricular organ: the area postrema in the rat. J. Comp. Neur. 219:328.

39. Shapiro, R. E., and R. R. Miselis. 1985. The central neural connections of the area postrema of the rat. J. Comp. Neurol. 234(3):344-364.

40. Edwards, G. L., and R. C. Ritter. 1981. Ablation of the area postrema causes exaggerated consumption of preferred foods in the rat. Brain Res. 216(2):265-276.

41. Contreras, R. J., T. Kosten, and E. Bird. 1984. Area postrema: part of the autonomic circuitry of caloric homeostasis. Fed. Proc. 43(15):2966-2968.

42. Kotz, C. M., M. K. Grace, C. J. Billington, and A. S. Levine. 1993. The effect of norbinaltorphimine, $\beta$-funaltrexamine, and naltrindole on NPY-induced feeding. Brain Res. 631:325-328.

43. Lambert, P. D., J. P. H. Wilding, A. A. M. Al-dokhayel, C. Bohuon, E Comoy, S. G. Gilbey, and S. R. Bloom. 1993. A role for neuropeptide-Y, dynor- 
phin, and noradrenaline in the central control of food intake after food deprivation. Endocrinology. 133(3):29-32.

44. Lambert, P. D., J. D. Wilding, G. A. A. al-Dokhayael, S. G. Gilbey, and S. R. Bloom. 1993. The effect of central blockade of kappa-opioid receptors on neuropeptide Y-induced feeding in the rat. Brain Res. 629(1):146-148.

45. Pages, N. M Orosco, C. Fournier, C. Rouch, A. Hafi, A. Gourch, E. Comoy, and C. Bohoun. 1991. The effects of chronic administration of morphine on the levels of brain and adrenal catecholamines and neuropeptide $\mathrm{Y}$ in rats. Gen. Pharmacol. 22(5):943-947.

46. Sahu, A., W. R. Crowley, and S. P. Kalra. 1990. An opioid-neuropeptide$\mathrm{Y}$ transmission line to luteinizing hormone $(\mathrm{LH})$-releasing hormone neurons: a role in the induction of LH surge. Endocrinology. 126(2):876-83.

47. Chang, C. L., Y. C. Tsai, S. S. Lin, and J. T. Cheng. 1992. Effect of premedication on the changes of neuropeptide Y (NPY) in anesthesia. Ma Tsui Hsueh Tsa Chi. 30(3):147-52.
48. Barraco, I. R. A. 1994. Nucleus of the Solitary Tract. CRC Press, Boca Raton, $435 \mathrm{pp}$.

49. Berk, M. L., and J. A. Finkelstein. 1982. Efferent connections of the lateral hypothalamic area of the rat: an autoradiographic investigation. Brain Res. Bull. $8(5): 511-26$

50. Carr, K. D., D. O. Aleman, T. H. Bak, and E. J. Simon. 1991. Effects of parabrachial opioid antagonism on stimulation-induced feeding. Brain Res. 545(1-2):283-6.

51. McKibbin, P. E., S. J. Cotton, S. McMillan, B. Holloway, R. Mayers, H. D. McCarthy, and G. Williams. 1991. Altered neuropeptide Y concentrations in specific hypothalamic regions of obese ( $\mathrm{fa} / \mathrm{fa}$ ) Zucker rats. Possible relationship to obesity and neuroendocrine disturbances. Diabetes. 40(11):1423-9.

52. Rising, R., I. T. Harper, A. M. Fontvielle, R. T. Ferraro, M. Spraul, and E. Ravussin. 1994. Determinants of total daily energy expenditure: variability in physical activity. Am. J. Clin. Nutr. 59(4):800-4. 